\title{
Support the Troops: Gulf War Homecomings and a New Politics of Military Celebration
}

\author{
David Fitzgerald
}

The celebrations that took place in the aftermath of the Persian Gulf War of 1991 stood out as the largest seen in the United States since the end of World War II, as hundreds of thousands of troops marched in triumphant parades in almost every major American city and in hundreds of small towns. But the pageantry did not simply celebrate American military and technological prowess. Spectators at these parades also engaged in a novel form of patriotism that emphasized unquestioning support for the troops. Representing a crucial moment in the American public's deepening veneration for U.S. soldiers and veterans, the Gulf War celebrations marked a turning point when the Vietnam-era image of the soldier as a broken or rebellious draftee was finally and purposefully eclipsed by the notion of the volunteer service member as hero.

In Jarhead, a memoir of his experiences as U.S. Marine sniper in the Persian Gulf War, Anthony Swofford depicted his homecoming from war as something of a disappointment. Describing the bus trip from San Bernardino to the Marine Corps base at Twentynine Palms, he "recalled pictures from the World War II victory parades in New York City" and remarked that "our twenty buses rambling through the high desert were a let-down in comparison," despite the thousands of cheering citizens lining the road to greet the returning troops. Swofford found himself "bored with the routine, and frustrated with the identity, the identity of the hero, being forced on me." In contrast to Swofford's discomfort, a Vietnam veteran who had been pulled onto the bus by a fellow Marine found the celebrations deeply moving. Swofford describes this man who "had no shoes on his dirty feet and wore tattered jeans and a faded camouflage blouse of indeterminate origin." Taking in the scene before him, "tears fell from the man's eyes and rolled down his deeply wrinkled and hurt face" and he "yelled to the bus, "Thank you, thank you, jarheads, for making them see we are not bad animals."'

Swofford may have felt underwhelmed by the scale of the Gulf War homecoming celebrations, but his convoy of twenty yellow buses was actually part of something much larger. Indeed, no American had seen military festivities on this scale since the end of World War II, as both large metropolitan centers and small towns eagerly organized victory parades. Such was the initial euphoria upon victory that White House staffers considered asking Congress to proclaim February 27 "VK Day" (Victory in Kuwait), something on a par with "Victory in Europe" or "Victory in Japan." 3 Indeed, even as Swofford made unfavorable

I would like to thank Sarah Phillips, Brooke Blower, the anonymous reviewers, and the editorial assistants at $M A H$ for the care and attention that they gave this essay. I also benefitted from comments from audiences at HOTCUS, SHAFR, and the UCC history research seminar. Finally, I give special thanks to Ruth Lawlor, David Ryan, and Sarah Thelen, who all read and commented on earlier drafts.

${ }^{1}$ Anthony Swofford, Jarhead: A Marine's Chronicle of the Gulf War and Other Battles (New York, 2003$), 250$.

${ }^{2}$ Ibid., 251.

${ }^{3}$ Carney Sub-Group of the Communications Working Group on the Gulf to David Demarest, "Memorandum for David Demarest, Re: Homecoming," Feb. 28, 1991, folder 29166-003, "Persian Gulf War 1991 [1],” Issues File, John Sununu Files, White House Office of the Chief Staff, George H. W. Bush Presidential Records, George Bush (C) The Author(s) 2019. Published by Cambridge University Press 
comparisons with World War II, the city of Twentynine Palms was planning a parade of five thousand Marines and sailors to offer thanks to the "returning heroes" on behalf of local communities. In a letter inviting President George H. W. Bush to attend, the organizing committee noted that "most communities of our great American nation have not experienced a true military parade since the allied victories of World War II." They drew a direct line between the soldiers of Desert Storm and veterans of earlier wars and promised that the Marines would "march, as their victorious predecessors once did in our earlier history in full battle gear along with various military vehicles and weapons."4

That commentators would reach so quickly for comparisons with earlier and much larger conflicts is striking, as is the fact that celebrations continued in some areas through August 1991, thus lasting much longer than the war itself. This outpouring of triumphalism, which seems out of proportion in retrospect, resulted from a convergence of pride in the accomplishments of a reformed military, guilt over the mistreatment of Vietnam veterans, and relief over an overwhelming victory in the Persian Gulf. Put together, this combination of pride, guilt, and relief produced a mass spectacle of militarism on the streets of American cities and towns. Crucially, those who participated in these celebrations-from politicians to protestors-made the quality and inherent goodness of the American soldier a central part of their focus, regardless of any broader disagreements about U.S. foreign policy.

For a crisis that transfixed American society for several months and that precipitated immense regional consequences, the Gulf War has received relatively limited scholarly attention. Scholars of foreign relations have focused on how that conflict acted both as a means of banishing the "Vietnam syndrome" and as a precursor to subsequent American wars in the greater Middle East, while military historians have examined the extent to which the conflict heralded a "revolution in military affairs." In recent years, historians have taken advantage of newly declassified records at the George H. W. Bush Presidential Library to situate the war within the Bush administration's broader foreign policy and its attempts to construct a "new world order." But an examination of the archives also reveals that these records can allow us to understand the domestic consequences of the war more clearly. Wary of another Vietnam, the Bush administration monitored and attempted to shape domestic opinion by

Presidential Library, College Station, TX [hereafter GBPL]. Bush Library materials for this article are drawn from the inventory of Freedom of Information Act (FOIA) request 1998-0099-F. White House Office of Record Management (WHORM) Alphabetical Files and WHORM Subject Files from this collection were processed at the document level; Staff and Office Files were processed at the folder level. Individual document numbers are available for WHORM files; folder numbers are available for Staff and Office Files.

${ }^{4}$ Cheryl Cook, "Invitation to President and Mrs. George Bush, from Twentynine Palms Victory Parade Committee," Mar. 27, 1991, document 208848 [3], ME002 Messages (Sent to Groups/Organizations, Subject File - General, White House Office of Records Management (WHORM)), GBPL.

${ }^{5}$ Andrew J. Bacevich, America's War for the Greater Middle East: A Military History (New York, 2016), 109-36; Lawrence Freedman and Efraim Karsh, The Gulf Conflict 1990-1991: Diplomacy and War in the New World Order (London, 1993); Steven Hurst, The United States and Iraq Since 1979: Hegemony, Oil and War (Edinburgh, UK, 2009); David Ryan and Patrick Kiely, eds., America and Iraq: Policy-Making, Intervention and Regional Politics (Abingdon, UK, 2009); Marilyn B. Young, “This Is Not Vietnam: This Is Not a Pipe," Middle East Report, no. 171 (1991): 21-24. On the military history of the war, see Rick Atkinson, Crusade: The Untold Story of the Persian Gulf War (New York, 1994); Stephen Biddle, "Victory Misunderstood: What the Gulf War Tells Us about the Future of Conflict," International Security 21, no. 2 (Oct. 1, 1996): 139-79; and Daryl G. Press, "The Myth of Air Power in the Persian Gulf War and the Future of Warfare," International Security 26, no. 2 (Fall 2001): 5-44.

${ }^{6} \mathrm{Hal} \mathrm{Brands,} \mathrm{Making} \mathrm{the} \mathrm{Unipolar} \mathrm{Moment:} \mathrm{U.S.} \mathrm{Foreign} \mathrm{Policy} \mathrm{and} \mathrm{the} \mathrm{Rise} \mathrm{of} \mathrm{the} \mathrm{Post-Cold} \mathrm{War} \mathrm{Order} \mathrm{(Ithaca,}$ NY, 2016), 298-316; Jeffrey Engel, ed., Into the Desert: Reflections on the Gulf War (New York, 2012); Jeffrey A. Engel, When the World Seemed New: George H. W. Bush and the End of the Cold War (New York, 2017), 376-414; Gary R. Hess, Presidential Decisions for War: Korea, Vietnam, the Persian Gulf, and Iraq (Baltimore, 2009), 153-220; David F. Schmitz, Brent Scowcroft: Internationalism and Post-Vietnam War American Foreign Policy (Lanham, MD, 2011), 137-70. 
framing the war and its aftermath as the antithesis to that earlier conflict. This framing, though, was not solely an elite project. Hundreds of communities across the United States organized their own pro-war rallies and victory celebrations. Requests for presidential acknowledgment of these rallies provide the historian with flyers, schedules, and press releases. Taken together, the papers of White House staffers and the mass of correspondence about rallies, small and large, invite an examination of both elite and vernacular expressions of pro-war patriotism. At all levels, a new kind of politics was on display, one that insisted upon reflexive support for the troops. Nowhere were these politics more prominently on display than during the homecoming celebrations in the aftermath of the war.

In some ways, the celebrations of 1991 present something of an outlier. Unlike other wars that necessitated longer, messier engagements, the Gulf War offered a comforting narrative of complete victory, followed by the triumphant return of the troops amid public celebrations. Unlike World War I, the Korean or Vietnam Wars, or even World War II, commentators did not worry about the challenges of re-integrating veterans into civilian society. The parades instead showcased the broader public's complete reverence for these heroic volunteers who existed outside the ordinary realm of ideological and political disagreement. The profusion of gratitude and triumphalism, in fact, represented the culmination of over a decade of work by the military and its supporters to restore its reputation after Vietnam. But the presence of millions of Americans in the streets celebrating the armed forces did not just reflect the improved standing of the military in American society; it also solidified a new set of relations. The Gulf War celebrations replaced the Vietnam-era image of the soldier as a broken or rebellious draftee with the unquestioned notion of the volunteer service member as hero.

From the early republic to the Cold War, pageantry played a key role in American political life and allowed citizens to participate in and to help define American political culture. ${ }^{7}$ As Americans took part in the 1991 celebrations, different actors performed particular roles: civilians as cheerleaders, war veterans as heroes, generals as symbols of strategic acumen, and military equipment as entertainment. Beyond the central cast of characters, additional groups also sought something from the parades. Conservative politicians emphasized the volunteer ethos of the troops who fought in the Gulf and sought to use this to advance policy goals and their reelection prospects. Defense contractors hoped that the celebration of military technology might help mitigate the budgetary effects of the coming post-Cold War defense drawdown. Commercial enterprises saw the festivities as an advertising opportunity, while antiwar protestors used the occasion to emphasize their credentials as patriots who supported the troops even as they decried the war itself. What all of these groups had in common was that they venerated the troops, no matter their other objectives.

Thus, even if Desert Storm veteran Swofford's cynicism about the national mood represented a misreading of the scale of the celebrations, his recollection of his homecoming accurately conveyed the ways in which the American public moved to rehabilitate the image of the American soldier. Both his discomfort with the identity of hero and the grateful tears of the Vietnam veteran who joined him on the bus revealed that, as much of the media's attention during the war had focused on technological wonders such as the F-117 Nighthawk stealth bomber and the Patriot missile system, now the American soldier was very much the centerpiece of the war's celebration and remembrance. ${ }^{8}$ In President Bush's address to a joint session

\footnotetext{
${ }^{7}$ David Waldstreicher, In the Midst of Perpetual Fetes: The Making of American Nationalism, 1776-1820 (Chapel Hill, NC, 1997); David Glassberg, American Historical Pageantry: The Uses of Tradition in the Early Twentieth Century (Chapel Hill, NC, 1990); Richard M. Fried, The Russians Are Coming! The Russians Are Coming! Pageantry and Patriotism in Cold-War America (New York, 1999).

${ }^{8}$ Much of the literature on the media and the Gulf War, especially that on television, focuses on technology, spectacle, and the notion of a "clean" war. Less has been written about depictions of soldiers. Indeed, much of Swofford's memoir is about the frustration of soldiers, who found themselves displaced by technology. On the media, spectacle, and war, see Jean Baudrillard, The Gulf War Did Not Take Place (Indianapolis, IN, 1995);
} 
of Congress on March 6, 1991, to mark the end of the war, he argued that the whole country could learn from the example of the Desert Storm soldiers. For Bush, these soldiers "accomplished more than even they may realize. They set out to confront an enemy abroad, and in the process, they transformed a nation at home."

An earlier draft of Bush's address to Congress even framed the administration's domestic policy agenda as one explicitly aimed at honoring these veterans. In this version, Bush would have proclaimed: "Let us honor those who have served us-those who have shown us all that America means to the world-by making certain that we here are worthy of them." ${ }^{10}$ This rhetorical flourish elevated the soldier in new ways: rather than thinking of soldiering in terms of service, the draft text in fact implied that American citizens had a duty not just to honor veterans, but to make themselves worthy of those soldiers. While Bush had little success in capitalizing on the Gulf War to pursue his domestic agenda, the emphasis on soldiers as uniquely heroic endured. In all of the postwar celebrations, from the National Victory parade in Washington, DC, to small-town homecomings, the soldier and the veteran comprised the heart of the festivities, and Americans celebrated them as noble, apolitical professionals, representing the United States at its best.

\section{The Shadow of Vietnam}

Large parades marked the end of the Civil War, World War I, and World War II, and while there were no national parades in the immediate aftermath of the Korean or Vietnam Wars, local groups did welcome individual units and soldiers home. Two factors, however, distinguished the events of 1991 from previous conflicts. First, the public expressed relatively little concern about how returning veterans might disrupt American society. In the summer of 1991, Americans of every political persuasion saw celebration of the troops as a relatively straightforward and unproblematic act. Second, the soldiers of Desert Storm were not citizen soldiers, temporarily mobilized for war, but professionals for whom military service was a way of life. The same had not been true of earlier conflicts.

Following the Civil War, the ordinary soldier-as opposed to the officer corps-became central to celebrations and commemorations for the first time. Not only did thousands of veterans march through the streets of Washington before large crowds at the Grand Review of the Armies in May 1865, but communities both North and South also erected statues of Johnny Reb and Billy Yank. ${ }^{11}$ Indeed, veterans and veterans' organizations figured heavily in postwar politics, as former soldiers leveraged their service in the elections of the 1870s and 1880s to win high office, and groups like the Grand Army of the Republic advocated for issues like patriotic education and veterans' pensions. ${ }^{12}$ Alongside this celebration of the veteran, though, percolated fears, especially in the North, that veterans were broken figures unable to resume their civilian lives, and therefore responsible for a postwar upsurge in crime and opioid abuse. ${ }^{13}$

Hamid Mowlana, George Gerbner, and Herbert Schiller, eds., Triumph of the Image: The Media's War in the Persian Gulf, a Global Perspective (Boulder, CO, 1992); Douglas Kellner, The Persian Gulf TV War (Boulder, CO, 1992); Martin Shaw, The New Western Way of War: Risk-Transfer War and Its Crisis in Iraq (London, 2005); George A. Lopez, "The Gulf War: Not So Clean," Bulletin of the Atomic Scientists 47, no. 7 (Sept. 1, 1991): 30-5.

${ }^{9}$ George H. W. Bush, "Address Before a Joint Session of the Congress on the Cessation of the Persian Gulf Conflict" (Online by Gerhard Peters and John T. Woolley, The American Presidency Project, Mar. 6, 1991), https://www.presidency.ucsb.edu/documents/address-before-joint-session-the-congress-the-cessation-the-persiangulf-conflict (accessed Dec. 19, 2018).

${ }^{10}$ Dan McGroarty and Peggy Dooley, "Draft Presidential Remarks: Joint Session of Congress, the Capitol, March 6, 1991," Mar. 5, 1991, folder 29166-004, "Persian Gulf War [2]”, Issues File, John Sununu Files, White House Office of the Chief Staff, GBPL.

${ }^{11}$ G. Kurt Piehler, Remembering War the American Way (Washington, DC, 2004), 47-67.

${ }^{12}$ David W. Blight, Race and Reunion: The Civil War in American Memory (Cambridge, MA, 2002), 64-97.

${ }^{13}$ David T. Courtwright, "Opiate Addiction as a Consequence of the Civil War," Civil War History 24, no. 2 (June 1978): 101-11; Brian Matthew Jordan, “Our Work Is Not Yet Finished': Union Veterans and Their 
Similarly, the ends of World War I and World War II triggered worries about veterans struggling to readjust to civilian society. In both cases, the demobilization process was slow and fraught with difficulties, leading to mass protests overseas from citizen soldiers impatient to return to their previous lives. ${ }^{14}$ Even as politicians, the media, and the general public lauded the achievements of American G.I.s in these wars, many Americans became disillusioned with the military as an institution, as the difficulties of demobilizing millions of troops and returning to a less-effective peacetime force tarnished the glow of victory. ${ }^{15}$ In 1945 , a question mark hung over returning veterans: "would they ... become a challenge to social stability? ... Could families and marriages survive the strain of reunion? Could educators adapt to the large numbers of veterans clamoring for entrance into universities and develop new teaching methods to accommodate them?"16

By 1991, Americans had forgotten these earlier difficulties and only the mythology of the "Good War" remained. If anybody invoked the end of World War II in the aftermath of Desert Storm, it was to offer a vision of the events of 1945 as a similarly positive, trouble-free celebration of victory. Instead, the shadow of the Vietnam War loomed over the preparations. In 1970, Nixon White House staffer William Safire had argued that there should be a national parade to mark the return of U.S. combat troops from Vietnam. He claimed that "we cannot permit peace to limp in unheralded, causing people to wonder retrospectively, 'when did the war end?"'17 However, apart from some local homecomings, such parades never took place. Vietnam veterans returned to an inadequate Veterans Administration hospital system and struggled to improve their minimal G.I. Bill benefits and to gain recognition for post-traumatic stress disorder and Agent Orange-related illnesses. ${ }^{18}$ To an even greater degree than their predecessors from the Civil War, World War I, World War II, or Korea, Vietnam veterans faced enormous reintegration challenges.

Given these struggles, many Vietnam veterans were dismayed by the public reaction to the release of hostages from the U.S. embassy in Tehran in January 1981. The fifty-two hostages, who had been held captive for 444 days, were greeted with parades in Washington, DC, and New York, and given lifetime passes to Major League Baseball games; all this presented a stark contrast to the silence that greeted many veterans returning from Vietnam. ${ }^{19}$ Writing

Unending Civil War, 1865-1872," Journal of the Civil War Era 5, no. 4 (Dec. 2015): 484-503; James Marten, “A Running Fight against Their Fellow Men: Civil War Veterans in Gilded Age Literature," Journal of the Civil War Era 5, no. 4 (Dec. 2015): 504-27; James Marten, Sing Not War: The Lives of Union \& Confederate Veterans in Gilded Age America (Chapel Hill, NC, 2011).

${ }^{14}$ Jennifer D. Keene, Doughboys, the Great War, and the Remaking of America (Baltimore, 2003), 132-44; Susan L. Carruthers, The Good Occupation: American Soldiers and the Hazards of Peace (Cambridge, MA, 2016), 191220.

${ }^{15}$ Brian McAllister Linn, Elvis's Army: Cold War GIs and the Atomic Battlefield (Cambridge, MA, 2016), 9-47.

${ }^{16}$ Michael D. Gambone, The Greatest Generation Comes Home: The Veteran in American Society (College Station, TX, 2005), 46; Mark D. Van Ells, To Hear Only Thunder Again: America's World War II Veterans Come Home (Lanham, MD, 2001); Thomas Childers, Soldier from the War Returning: The Greatest Generation's Troubled Homecoming from World War II (Boston, 2010).

${ }^{17}$ H. R. Haldeman, "Memorandum for Dr. Kissinger," Nov. 25, 1970, folder "Memos J-M," Box 47, Staff Members Office Files, H.R. Haldeman, White House Subject Files, Richard Nixon Presidential Library and Museum, Yorba Linda, CA.

${ }^{18}$ Mark Boulton, Failing Our Veterans: The G.I. Bill and the Vietnam Generation (New York, 2014); Edwin A. Martini, Agent Orange: History, Science, and the Politics of Uncertainty (Amherst, MA, 2012); Gerald Nicosia, Home to War: A History of the Vietnam Veterans' Movement (New York, 2001); Bob Greene, Homecoming: When the Soldiers Returned from Vietnam (New York, 1989); Jerry Lembcke, The Spitting Image: Myth, Memory, and the Legacy of Vietnam (New York, 2000).

${ }^{19}$ The exception to this was Operation Homecoming, the 1973 return of nearly 600 prisoners of war from Vietnam. This group received loud public support on their return, but their experience, coupled with suspicions that some POWs had been left behind, also fed into fears of national decline. Michael J. Allen, Until the Last Man Comes Home: POWs, MIAs, and the Unending Vietnam War (Chapel Hill, NC, 2009); Natasha Zaretsky, 
about the episode, a Boston Globe columnist reflected on the contrast and argued that "we already had heroes ... the veterans of the Tet offensive, Hamburger Hill, Marine firebase Ross in the DMZ, but we didn't recognize them. We turned our backs on them ... and blamed them for the policies that were actually set in the White House." ${ }^{20}$

The Iran hostage crisis thus created a newfound appreciation for Vietnam veterans. An eight-page Time Magazine cover story on "The Forgotten Warriors" in July 1981 reflected this shift. The article quoted Doug Kamholz, a former antiwar activist who said that "I have been feeling guilty about blaming the war on the warriors. I never yelled 'baby killer,' but I didn't oppose it either. It was a moral and political mistake for the anti-war movement not to see the difference. I hope it's not too late." ${ }^{21}$ Veteran activists channeled this sympathy into the ongoing task of memorialization, with veteran-led projects such as the Vietnam Veterans Memorial on the National Mall and hundreds of other smaller monuments springing up across the country. ${ }^{22}$ By the mid-1980s, the Vietnam veteran had gone from pariah to a victim worthy of sympathy. While Time's story on the veterans concluded with a veteran's wife declaring, "with a wan smile: 'I'd love to see a great big parade-one time-national," ${ }^{23}$ she would not need to wait long. On the tenth anniversary of the war's end, 25,000 Vietnam veterans, many of them dressed in remnants of their uniforms, received a ticker tape parade in New York City in May 1985, belatedly following the footsteps of the Iran hostages. A year later, 200,000 marched in Chicago, cheered on by 500,000 spectators; 100,000 marchers, led by retired General William C. Westmoreland, turned out in Houston in March $1987 .^{24}$

The Vietnam veterans' fight for recognition took shape within a broader cultural shift in the 1980s. President Ronald Reagan's embrace of Vietnam as a "noble cause" was symptomatic of revisionism about that war specifically, but extended to cultural portrayals of soldiers more generally as well. While memorialization practices-such as the building of monuments on the National Mall—framed citizenship in terms of soldiering, popular media, from combat magazines to Tom Clancy's series of popular technothriller novels to action movies such as Top Gun (1986), promoted visions of a highly competent military, full of heroic warriors adept at modern war. ${ }^{25}$ These depictions were not entirely wishful thinking. The post-Vietnam military

No Direction Home: The American Family and the Fear of National Decline, 1968-1980 (Chapel Hill, NC, 2007), 25-70.

${ }^{20}$ Jeremiah Murphy, "We Already Had Heroes," Boston Globe, Feb. 8, 1981, cited in Paul Camacho, "The Future of the Veterans' Lobby and Its Potential Impact for Social Policy," in Jayne Susan Werner and David Hunt, eds., The American War in Vietnam (Ithaca, NY, 1993), 114.

${ }^{21}$ Lance Morrow, "The Forgotten Warriors," Time, July 13, 1981, 18-35, here 33.

${ }^{22}$ The literature on the collective memory of the Vietnam War is extensive. For a representative sample, see David Kieran, Forever Vietnam: How a Divisive War Changed American Public Memory (Amherst, MA, 2014); Patrick Hagopian, The Vietnam War in American Memory: Veterans, Memorials, and the Politics of Healing (Amherst, MA, 2009); Myra MacPherson, Long Time Passing: Vietnam and the Haunted Generation (Bloomington, IN, 1984); David Ryan, "Vietnam in the American Mind: Narratives of the Nation and the Sources of Collective Memory," in Rüdiger Kunow and Wilfried Raussert, eds., Cultural Memory and Multiple Identities (Berlin, 2008), 109-28; Robert D. Schulzinger, A Time for Peace: The Legacy of the Vietnam War (New York, 2006); and Marita Sturken, Tangled Memories: The Vietnam War, the AIDS Epidemic, and the Politics of Remembering (Berkeley, CA, 1997).

${ }^{23}$ Morrow, "The Forgotten Warriors," 35.

${ }^{24}$ Jane Gross, "New York Pays Homage to Vietnam Veterans," The New York Times, May 7, 1985, A1; "Vietnam Veterans in Chicago Parade Cheered by Crowds," The New York Times, June 14, 1986, 6; "Vietnam Veterans March in Houston," The Washington Post, May 24, 1987, 18.

${ }^{25}$ Susan Jeffords, Hard Bodies: Hollywood Masculinity in the Reagan Era (New Brunswick, NJ, 1994); James William Gibson, Warrior Dreams: Violence and Manhood in Post-Vietnam America (New York, 1994); Kristin Ann Hass, Sacrificing Soldiers on the National Mall (Chapel Hill, NC, 2013); Andrew J. Bacevich, The New American Militarism: How Americans Are Seduced by War (New York, 2005), 97-121; H. Bruce Franklin, MIA, or Mythmaking in America (New Brunswick, NJ, 1993), 127-64; Walter L. Hixson, “Red Storm Rising': Tom Clancy Novels and the Cult of National Security," Diplomatic History 17, no. 4 (Oct. 1993): 599-614. 
underwent significant reforms and updated its doctrine, equipment, and training. The Nixon administration established the All-Volunteer Force in 1973 and, after a troubled beginning, it had stabilized by the mid-1980s. ${ }^{26}$ When the armed forces deployed to Saudi Arabia in 1990, media commentators highlighted the more racially diverse, mature, and well-trained volunteer force as a symbol of the strength and diversity of the United States-a move that Melani McAlister has termed "military multiculturalism." ${ }^{27}$ This combination of increasing military confidence, defense reforms, and a changed culture translated into concrete attitudinal shifts; in August 1990, Gallup polling indicated that 68 percent of Americans had a "great deal" or "quite a lot" of confidence in the military, up from a 1979 nadir of 50 percent. ${ }^{28}$

These changes mark the second major difference between the Gulf War and previous homecomings: unlike the draftees and short-term volunteers coming home from previous wars, the soldiers returning from the Persian Gulf belonged to a professional standing army. The troops marching in the streets of American cities in the summer of 1991 were not citizen soldiers on the cusp of demobilization; they were professionals who could expect to be deployed again in the near future.

Many military leaders made the connection between the scale of the victory in the Gulf and the post-Vietnam reforms that included new doctrine, new equipment, and, crucially, the All-Volunteer Force. ${ }^{29}$ When the Senate Armed Services Committee asked Major General Barry McCaffrey how the military won the war so quickly, he replied that "this war didn't take 100 hours to win, it took 15 years." ${ }^{\text {"N }}$ The Army's official history of the conflict, Certain Victory, highlighted the changes by focusing on the figure of Steven Slocum, who had served in Vietnam as a Specialist Fourth Class and in the Gulf as a Command Sergeant Major. Whereas Specialist Slocum had returned from Vietnam in 1968 to no fanfare, Command Sergeant Major Slocum returned from the Gulf decades later with 2,000 troops from his brigade to "thank you's" from everyone from the flight attendant on his chartered Pan Am 747 to the thousands waiting "with fluttering flags and banners" at Pope Air Force Base, North Carolina. ${ }^{31}$ Thus, for the Army's official history, the homecoming celebrations of the spring and summer of 1991 were the natural culmination of decades spent rebuilding.

This story of redemption and rebuilding also became a staple of the memoirs of the generals who served in Vietnam as young officers. For these figures, Operation Desert Storm affirmed that the military's post-Vietnam reforms had succeeded. Generals such as Colin Powell, Norman Schwarzkopf, Jr., and Tommy Franks told stories of their frustrations in Vietnam followed by years of hard work to rebuild the military before finding vindication in the deserts of the Arabian Peninsula. ${ }^{32}$ As Andrew Bacevich observes, "Virtually every one of these narratives

\footnotetext{
${ }^{26}$ As Beth Bailey notes, in 1980 only 54 percent of Army recruits were high school graduates and over half were Category IV (those whose scores are between the tenth and thirtieth percentile on the Armed Forces Qualifying Test), but by 1987, over 91 percent of new recruits had graduated from high school and only 4 percent were Category IV. Beth Bailey, America's Army: Making the All-Volunteer Force (Cambridge, MA, 2009), 197. On doctrinal reforms, see Richard Lock-Pullan, U.S. Intervention Policy and Army Innovation: From Vietnam to Iraq (London, 2005).

${ }^{27}$ Melani McAlister, Epic Encounters: Culture, Media, and U.S. Interests in the Middle East since 1945 (Berkeley, CA, 2005), 235-59.

${ }^{28}$ Gallup Inc., "Confidence in Institutions," http://www.gallup.com/poll/1597/Confidence-Institutions.aspx (accessed Nov. 26, 2018).

${ }^{29}$ James F. Dunnigan and Raymond M. Macedonia, Getting It Right: American Military Reforms After Vietnam to the Gulf War and Beyond (New York, 1993); James Kitfield, Prodigal Soldiers: How the Generation of Officers Born of Vietnam Revolutionized the American Style of War (Washington, DC, 1997).

${ }^{30}$ Barry R. McCaffrey, "Desert Shield and Desert Storm Operations Overview," testimony before the Committee on Armed Services, United States Senate, 102nd Cong. 1st sess., May 9, 1991, 117.

${ }^{31}$ Robert H. Scales, Certain Victory: The U.S. Army in the Gulf War (Washington, DC, 1993), 355-57.

${ }^{32}$ Tommy R. Franks, American Soldier (New York, 2005); Colin L. Powell and Joseph E. Persico, My American Journey: An Autobiography (New York, 1995); Norman Schwarzkopf, It Doesn't Take a Hero: The Autobiography of
} 
conforms to a prescribed formula.... From his experience in a lost war, the protagonist derives certain essential truths that he vows to apply if ever called upon in some future crisis to serve in a position of authority." In these memoirs, the protagonist returns home from war to find his fellow citizens shunning those who serve, but commits himself to the military, "rising through the ranks during a lengthy apprenticeship. When his moment finally arrives, he orchestrates a great victory, by implication showing how Vietnam ought to have been fought. In vanquishing the enemy, he also helps heal old wounds at home, promoting both reconciliation and national renewal." ${ }^{33}$ The most vivid example of this genre is Into the Storm, an account of the ground war in the Persian Gulf co-authored by Tom Clancy and General Fred Franks, who commanded VII Corps throughout the conflict. After losing a leg in Cambodia in 1971, Franks underwent his personal "Valley Forge" of recovery. As his own body heals, the Army itself is healed and rebuilt by veterans of Vietnam. Franks then takes command of a well-trained and well-equipped Armored Corps and defeats Saddam Hussein's vast army in just 100 hours of combat. ${ }^{34}$ For the military, therefore, the parades of the summer of 1991 would celebrate the renewed health of the armed forces as they savored victory in Iraq.

Despite these triumphant postwar narratives, however, the restored public confidence in the armed forces still harbored a certain brittleness. As Adrian Lewis argues, while the military may have "recovered materially, technologically and qualitatively during the Reagan Administration, it had not completely recovered emotionally and psychologically." ${ }^{35}$ Although the 1983 victory in Grenada had seemed all but assured, American units suffered a number of coordination, communication, and intelligence failures during the initial invasion. These difficulties echoed problems not only seen in Vietnam, but also the more recent botched attempt to rescue American hostages in Tehran, a debacle the military found humiliating.

Iraq posed a much bigger threat. While many commentators expressed confidence about American prospects, pre-war media coverage emphasized that Iraq possessed the fourth largest army in the world, one hardened by nearly a decade of war with Iran. The Veterans Administration made arrangements to clear hospital beds for the anticipated flow of wounded soldiers. ${ }^{36}$ Analysts estimated that the war would result in between 10,000 and 20,000 American casualties. ${ }^{37}$ While not on the scale of Vietnam-era protests, a substantial antiwar movement had emerged, and the Senate only narrowly voted to authorize the use of military force, with the resolution passing 52 votes to $47 .^{38}$ Sales of gas masks boomed in January 1991, and some wrote to local newspapers to suggest that the crisis called for the planting of World War II-type "victory gardens." 39

Amidst these fraught arguments over the conflict in the Persian Gulf, all sides emphasized support for the troops. Senate Majority Whip, Wendell Ford (D-KY), who had voted against

General H. Norman Schwarzkopf (New York, 1993); Hugh Shelton, Ronald Levinson, and Malcolm McConnell, Without Hesitation: The Odyssey of an American Warrior (New York, 2010).

${ }^{33}$ Andrew Bacevich, “A Modern Major General,” New Left Review 29 (Oct. 2004).

${ }^{34}$ Tom Clancy and Fred Franks, Into the Storm: A Study in Command (New York, 1998).

${ }^{35}$ Adrian R. Lewis, The American Culture of War: The History of U.S. Military Force from World War II to Operation Iraqi Freedom (Abingdon, UK, 2006), 312.

36“Is the VA Ready?” DAV Magazine, Oct. 1990, folder 03194-004, “Persian Gulf Working Group," Paul McNeill Files, White House Office of Communications, GBPL.

37"Potential War Casualties Put at 100,000," Los Angeles Times, Sept. 5, 1990, 2.

${ }^{38}$ W. Lance Bennett and David L. Paletz, eds., Taken by Storm: The Media, Public Opinion, and U.S. Foreign Policy in the Gulf War (Chicago, 1994); Frederick Fico, Linlin Ku, and Stan Soffin, "Fairness, Balance of Newspaper Coverage of U.S. in Gulf War," Newspaper Research Journal 15, no. 1 (Jan. 1994): 30-43; Robert A. Hackett and Yuezhi Zhao, "Challenging a Master Narrative: Peace Protest and Opinion/Editorial Discourse in the US Press During the Gulf War," Discourse \& Society 5, no. 4 (Oct. 1994): 509-41; John E. Mueller, Policy and Opinion in the Gulf War (Chicago, 1994).

${ }^{39}$ David Treadwell, “Americans Willing to Pay for Bit of Security," Los Angeles Times, Jan. 23, 1991, A11; Ivetta Burch, "Readers Write-It's Time Again for Victory Garden,” Owensboro Messenger-Inquirer, Feb. 6, 1991, 7A. 
the war, declared that "we have a profound responsibility to ensure that the tragedy of the Vietnam veterans is not repeated" and called for every American to "reach out personally to let our service men and women and veterans know that their essential contribution to democracy is appreciated." ${ }^{40}$ Indeed, Americans sent thousands of care packages to soldiers stationed in Saudi Arabia and elsewhere, and many displayed yellow ribbons in front yards and on jacket lapels. ${ }^{41}$ Celebrities embraced those serving in the Gulf, most notably Whitney Houston, whose bravura Super Bowl rendition of "The Star Spangled Banner" aired ten days into the conflict. ${ }^{42}$ The lyrics of the "Voices That Care" single-recorded in February 1991 by a super group including Celine Dion, Will Smith, Michael Bolton, Meryl Streep, Jean-Claude Van Damme, and Kevin Costner-revealed how entertainers might embrace the troops without necessarily endorsing the war. Celine Dion first intoned, "I'm not here to justify the cause / Or to count up all the loss / That's all been done before," and the celebrity chorus next joined in: "I just can't let you feel alone / When there's so much love at home / We're sending out to you." ${ }^{33}$

Such messages sent fundamentally emotional, apolitical messages of support to the troops and their families. Indeed, even those who opposed the war made a point of publicly displaying their support for the troops. Todd Gitlin, for example, a prominent antiwar figure during the Vietnam War and an opponent of U.S. military intervention in the Gulf, donated blood with NBC News cameras rolling. ${ }^{44}$ That Gitlin made such a gesture demonstrates how the notion of American soldiers as apolitical and worthy professionals had become an article of faith in American politics. ${ }^{45}$ Given the combination of widespread veneration of soldiers, guilt over the Vietnam experience, and fears over the level of casualties that the United States would sustain in a war with Iraq, the nation was primed for the explosion of joy and celebration that occurred with the rapid and successful conclusion of the war on February 28, 1991.

\section{"This Could Lay Extremely Solid Foundations for 1992": The Bush White House and Homecoming Planning}

On the very day that President Bush declared a ceasefire in the Gulf, popular author Tom Clancy published an opinion piece in The Los Angeles Times that called for victory parades for the veterans of Operation Desert Storm. Clancy acknowledged "how effective our weapons were" but also declared that "there is no truer measure of any society than its armed forces. In

\footnotetext{
${ }^{40}$ Wendell F. Ford, "Press Release: Ford Urges Kentucky Towns and Cities to 'Adopt' Servicemen and Women in the Persian Gulf,” Dec. 17, 1990, folder 06837-007, White House Office of Media Affairs, Subject Files: Congress, GBPL.

${ }^{41}$ For the history of the yellow ribbon and its use during the Gulf War, see Jack Santino, "Yellow Ribbons and Seasonal Flags: The Folk Assemblage of War," The Journal of American Folklore 105, no. 415 (Winter 1992): 19-33; George Mariscal, "In the Wake of the Gulf War: Untying the Yellow Ribbon," Cultural Critique, no. 19 (Autumn 1991): 97-117; and Gerald E. Parsons, "How the Yellow Ribbon Became a National Folk Symbol," Library of Congress American Folklife Center: Folklife Center News 13, no. 3 (Summer 1991): 9-11.

${ }^{42}$ Danyel Smith, "When Whitney Hit the High Note," ESPN.com, Feb. 1, 2016, http://www.espn.com/espn/ feature/story/_id/14673003/the-story-whitney-houston-epic-national-anthem-performance-1991-super-bowl (accessed Nov. 25, 2018); Chuck Philips, "Stars Voice Their Support of Gulf Forces," Los Angeles Times, Feb. 6, $1991, \mathrm{~F} 1$.

${ }^{43}$ David Foster, "Voices That Care Lyrics," MetroLyrics, http://www.metrolyrics.com/voices-that-care-lyricsvoices-that-care.html (accessed Mar. 14, 2018).

${ }^{44}$ Gitlin argued that the selective use of images from his blood donation effectively cancelled out his stance against the war. Todd Gitlin, "On Being Sound-Bitten: Reflections on Truth, Impression, and Belief in a Time of Media Saturation,” Boston Review 16, no. 6 (Dec. 1991): 15-7.

${ }^{45}$ On the debate over the extent to which the Vietnam-era media was "anti-troop" and the extent to which memories of that war hamstrung the Gulf War protestors, see Thomas D. Beamish, Harvey Molotch, and Richard Flacks, "Who Supports the Troops? Vietnam, the Gulf War, and the Making of Collective Memory," Social Problems 42, no. 3 (Aug. 1995): 344-60.
} 
uniform you will find the best and worst, the tools, the people, the ideas, all distilled in one place." He closed with this appeal:

How about a few parades? How about the collective thank you that was cruelly denied to the last class of American warriors? We give parades to baseball and football teams who win at games. These kids now finishing their job are America's Team. They wear our colors. Can we do any less for them? The military has learned its lessons from Vietnam. What about the rest of us? ${ }^{46}$

Clancy's appeal fell on fertile ground: in a USA Today poll taken in early March, 86 percent of respondents said that they would go to a parade for hometown soldiers. ${ }^{47}$ Moreover, even as Clancy published his piece, White House Chief of Staff John H. Sununu kept on his desk a draft schedule of homecoming events. He had solicited ideas for managing the celebrations from a Washington public relations consultant on February 22, two days before the ground campaign in Kuwait started. ${ }^{48}$

Indeed, the Bush administration quickly spotted the potential for partisan political gain afforded by a celebration of the troops who had won the war so swiftly. Supporters urged the White House to make maximum use of the impending victory celebrations. As one political operative noted, "If done right, this could lay extremely solid foundations for 1992." "Writing to Bush, House Minority Whip Newt Gingrich offered ideas for the president's upcoming address to a Joint Session of Congress, using the volunteer ethos of the military to advance conservative policies. Gingrich urged Bush to tell Congress that "one thing we must not forget is that the brave men and women who participated in Operation Desert storm did so as volunteers-they chose to risk their lives for principle, for honor, for country and for a better, safer world. They volunteered to do the hard work of freedom." He wanted Bush to call on Americans to "join with that volunteer army of freedom" to make the twenty-first century

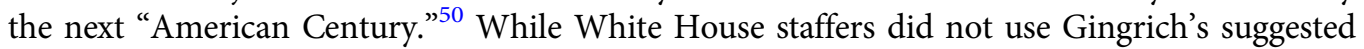
language in the actual address to Congress, Bush agreed with Gingrich's claim that "our military today is fundamentally better than it was ten years ago." He celebrated the "first-class talent" that "went halfway around the world to do what is moral and just and right," and claimed that the victory belonged to "the privates and the pilots, to the sergeants and the supply officers, to the men and women in the machines and the men and women who made them work." ${ }^{\text {Fo }}$ For both Bush and Gingrich, the volunteer military stood at the heart of what had gone right in Desert Storm.

Others emphasized volunteerism as a quintessentially American trait. A concept paper sent to the White House Office of National Service made the connection between the skills displayed by the military in the Gulf and the needs of modern American capitalism. According to the paper's author, "American enterprises increasingly require employees with the experience and qualities shown by the troops. To compete in the global marketplace, most US

\footnotetext{
${ }^{46}$ Tom Clancy, "How About a Few Parades?" Los Angeles Times, Feb. 28, 1991, B13, in folder 03195-008, Persian Gulf Working Group, Paul McNeill Files, White House Office of Communications, GBPL.

47“Communities Make Homecoming Plans," n.d., folder 03195-014, "Persian Gulf Working Group: Surrogates [2]," Paul McNeill files, White House Office of Communications Files, GBPL.

${ }^{48}$ Roy Pfautch, "Memorandum to John Sununu: The National Welcome Home," Feb. 22, 1991, folder 04733-005, "Desert Storm: Events," Sig Rogich Files, White House Office of Public Events and Initiatives, GBPL.

${ }^{49}$ Michael Bayer, "Memorandum to Jim Pinkerton: Coordination of Desert Storm Homecoming Events," Mar. 4, 1991, folder 04733-005, "Desert Storm: Events," Sig Rogich Files, White House Office of Public Events and Initiatives, GBPL.

${ }^{50}$ Newt Gingrich, "Memorandum to John Sununu: Suggested Rhetoric for 3/6 Joint Speech,” Mar. 4, 1991, folder 29166-004, "Persian Gulf War [2]," Issues File, John Sununu Files, White House Office of the Chief Staff, GBPL.

${ }^{51}$ Bush, "Address Before a Joint Session of the Congress on the Cessation of the Persian Gulf Conflict."
} 
manufacturers and service industries find they must delegate responsibility for precision operations to employees well down the line." Desert Storm veterans fit the bill perfectly because, "as volunteer recruits they performed on time, in time and in teams.... They exercised savvy, courage and leadership in performing their missions." ${ }^{\text {"2 }}$

This analysis drew heavily on a Washington Post column by Steven Rosenfeld that celebrated the victory over Iraq as springing from the democratic ideology of the U.S. military. Rosenfeld cited Marine Corps Colonel W. C. Gregson, who claimed that U.S. military doctrine "counts heavily on and encourages the initiative, skills, and courage of the individual and the small-unit leaders." According to Gregson, this worked only because "our armed forces personnel are not 'simple soldiers' who slavishly serve the hierarchy, as in totalitarian forces. In the democratic tradition, they are the purpose around which all our efforts revolve." Rosenfeld concluded by arguing that "to walk in American footsteps, other governments must change their basic political ways-loosen up central control, devolve authority to lower levels, reward individual initiative.... Let us ship our field manuals-and the Bill of Rights. This is the wonderfully subversive lesson of the war." ${ }^{" 53}$ For Rosenfeld and other observers, the volunteer soldiers of Desert Storm not only displayed tactical and operational mastery, but also the best American capitalist values of personal responsibility and individual enterprise.

Such was the admiration for the victors of Desert Storm that several public relations firms believed the administration should use them to advance its domestic policy goals of shrinking the size of the federal government and promoting private volunteerism. Hill + Knowlton Strategies, a firm with close ties to both the administration and the Kuwaiti government, suggested that Bush appoint a hero of Desert Storm, such as General Schwarzkopf or Powell, to run "Operation Domestic Prosperity," a 100-day initiative to make the United States a "home fit for heroes" by pressuring Congress to pass the Bush administration's domestic agenda. ${ }^{54}$ Recalling the "freedom trains" of the early Cold War, they also suggested a "victory train" stocked with veterans to tour the nation and celebrate "the men, women, and technology of Desert Storm." 55 This would be accompanied by a "freedom flotilla" of U.S. Navy and merchant marine vessels sailing around the United States, and a giant yellow ribbon stretching completely across it. ${ }^{56}$ Burson-Marsteller, a rival to Hill + Knowlton, proposed that the Department of Defense should carefully handpick and give media training to returning service members and then send them out to "maintain and expand in a meaningful way the national sense of pride, accomplishment, and good feeling generated by Operation Desert Storm.." ${ }^{\text {"7 }}$ Most ambitious of all was a suggestion from Kenneth Smith, CEO of a private consulting firm with ties to the Republican Party. ${ }^{58}$

\footnotetext{
${ }^{52}$ Frances Brigham Johnson to Clark Irvin, "Welcoming the Troops Home to New Opportunities: Hometown Volunteers Can Make a Difference," Apr. 2, 1991, folder 03630, General Files: Veteran and Operation Desert Storm Information, Clark Kent Irvin Files, White House Office of National Service, GBPL.

${ }^{53}$ Stephen S. Rosenfeld, "Democracy's War," Washington Post, Mar. 29, 1991, A21.

${ }^{54}$ On behalf of Kuwait, Hill+Knowlton coordinated false testimony given to the House Human Rights Caucus in October 1990, where a 15-year-old Kuwaiti girl claimed to have witnessed Iraqi soldiers taking babies out of incubators in a Kuwaiti hospital and leaving them to die. John R. MacArthur, "Remember Nayirah, Witness for Kuwait?” New York Times, Jan. 6, 1992, A17.

${ }^{55}$ The 1947-1949 "freedom train" was a travelling exhibit designed to "sell America to Americans" by displaying artifacts such as original copies of the Constitution, the Bill of Rights, and the Declaration of Independence. Fried, The Russians Are Coming!, 29-50.

${ }^{56}$ Craig L. Fuller, "Memorandum for John Sununu," Mar. 27, 1991, folder 04733-005, "Desert Storm: Events," Sig Rogich Files, White House Office of Public Events and Initiatives, GBPL.

${ }^{57}$ Thomas D. Bell, "Memorandum for Ed Rogers: Expanding the Spirit of Desert Storm,” Apr. 2, 1991, folder 04733-005, "Desert Storm: Events," Sig Rogich Files, White House Office of Public Events and Initiatives, GBPL.

${ }^{58}$ Smith was the founder and CEO of the International Development and Management Group, a consulting firm based in Alexandria, Virginia. Formerly a Nixon White House staffer, he had been appointed to various national advisory councils by President Reagan. His firm specialised in building strategic partnerships between industry and government.
} 
He suggested that the administration train the more than 500,000 Gulf War veterans as "Desert Storm Community Service Volunteers" for an unspecified purpose. According to Smith:

The people who participated in Desert Storm are truly an enormous national asset.... America's young people desperately need heroes-real heroes. Real people in real walks of life who do the real things that make America what it is. People who serve their country. People who earn their money, people who have a commitment to excellence and competence, people who believe in the value of service. ${ }^{59}$

Unlike previous homecomings, in which the public and government officials worried about how to reintegrate veterans back into society and what sort of supports they would need, the Gulf War veterans would instead be the ones to provide support and inspiration to broader American society.

Yet White House staffers expressed reluctance to fully embrace such ambitious programs. In correspondence with staff in the Office of National Service, Mary Hinds, for example, of the president's Points of Light Foundation, questioned proposals that attempted to "incorporate military resources and organization to resolve domestic social problems" in lieu of substantive programs that "include and respect all segments of our society." Hinds argued that "the military's function is to be ready to defend the nation so that Americans have the opportunity to pursue solutions to social problems. The military and 'wars' on specific issues with American society are not the answer." 60

The Department of Defense indicated similar reluctance to engage in large-scale social programs, but it otherwise proved eager to make use of the celebrations to promote the military. The Pentagon Public Affairs office contacted the White House about the forthcoming homecomings and shared some of its key messages. Themes that the Pentagon planned to emphasize included the idea that "we proved ourselves the best fighting force that has ever been fielded by our nation"; "America's half million heroes are coming home"; the "post-Vietnam syndrome is definitely over"; and, most tellingly, that "technology works-investment in a strong defense remains important-there are future threats that are impossible to predict." ${ }^{\text {" For the }}$ Department of Defense, the parades offered the chance to showcase American technology and promote investment in the military.

The Pentagon Public Affairs office also quickly grasped the scale of the upcoming celebrations and noted that the logistics of troop deployments meant that "enthusiasm for greeting returning troops from Operation Desert Storm may outrace our government's ability to bring them home." Because it was "impossible to predict precisely how rapidly the drawdown will occur or in what order," the office argued that "the homecoming should not be planned and managed by centralized government agencies, including $\mathrm{DoD}$ and the White House. Our role is to be responsive to what is clearly an outpouring of local, state, and national-level support, and to provide assistance and guidance." ${ }^{62}$ This contrasted starkly with what one Republican operative promoted-the idea of running something called "Operation Grateful Nation" on July 4. He wrote:

\footnotetext{
${ }^{59}$ Kenneth Smith, "Memorandum for David Demarest: Desert Storm Heroes as Community Service Leaders," Mar. 15, 1991, folder 07637-09, White House Office of National Service, GBPL.

${ }^{60}$ Mary Hinds, "Memorandum for Richard Schubert: Bringing the War Home," Mar.15, 1991, folder 07637-09, ONS/Desert Storm 2/20/91, White House Office of National Service, GBPL.

${ }^{61}$ Daniel J. Kalinger, “Memorandum to David Demarest, David Carney: Homecoming Planning,” Mar. 4, 1991, folder 04733-005, "Desert Storm: Events," Sig Rogich Files, White House Office of Public Events and Initiatives, GBPL.

${ }^{62}$ Ibid.
} 
The White House must be intimately involved in the planning and the coordination of events to be sponsored by the private and public sectors throughout the Nation to assure that: (i) the President is given every opportunity to participate in selected local events; (ii) the local planners have the benefit of White House advice and resource management; and (iii) the celebrations coincide with National events, including Armed Forces Day, Memorial Day, July 4 th, and Veterans Day. ${ }^{63}$

Ultimately, the White House took the Pentagon's advice, keeping tabs on various planned celebrations, but taking a step back to allow others to run them "while paying particular attention to events that might offer political benefit to the administration." In his March 6 address to Congress, Bush called for "every community in this country to make this coming Fourth of July a day of special celebration for our returning troops. They may have missed Thanksgiving and Christmas, but I can tell you this: For them and for their families, we can make this a holiday they'll never forget." ${ }^{64}$ Americans in both big cities and small towns quickly responded to Bush's request, and parade committees sprang up across the country. Even though not centrally planned, these parades echoed the themes the White House had hoped to emphasize even before the end of the war: soldiers and veterans (including Vietnam veterans) were heroes, American technology was triumphant, and the strength of a professional, allvolunteer military was clear.

\section{"Making Certain That We Here Are Worthy of Them": The Homecoming Parades and Mass Spectacle}

Planning for the parades emphasized both patriotism and spectacle. At the invitation of White House Chief of Staff John Sununu, political consultant Roy Pfautch sent a list of suggested events to the White House on February 22. In addition to a New York City ticker-tape parade and a national celebration in Washington, DC, Pfautch wanted to see a "parade of stars" in Hollywood, with a star assigned to each battalion, and a "land and water" salute in Chicago that would utilize the Lakefront's Grant Park to stage an aerial display and an amphibious landing, demonstrating "the full range of cooperative endeavor between water and air." ${ }^{65}$ Even though the White House elected not to coordinate the parades, Pfautch's suggestions nevertheless foreshadowed the actual celebrations in important ways. Celebrities and technology would figure prominently alongside the troops, and organizers did as much as possible to put on spectacular displays of military might.

The initial celebrations, such as an event in Texas Stadium, home of the Dallas Cowboys, that attracted 30,000 revelers, were often pro-troop rallies turned into improvised victory parties, and thus emphasized flag-waving and patriotism rather than military hardware. For later homecomings, martial pageantry formed a prominent part of the festivities, even in locations as small as Hueytown, Alabama (population: 15,000). The mayor of Hueytown sent the White House an invitation to the May 18 celebration, describing a military display including "helicopters, tanks, artillery" and a day of festivities that would open with an "Army Special Forces flyover, followed by two squads of troops rappelling from hovering helicopters onto field in full battle dress to engage in mock battle, complete with blank ammo." ${ }^{\text {"W6 }}$ While not everyone opted for a full-scale mock combat demonstration, almost every city across the United States put on some sort of homecoming celebration. The major cities and communities adjacent to large

\footnotetext{
${ }^{63}$ Michael Bayer, "Memorandum to Jim Pinkerton: Coordination of Desert Storm Homecoming Events," Mar. 4, 1991, folder 04733-005, Sig Rogich Files, White House Office of Public Events and Initiatives, GBPL.

${ }^{64}$ Bush, "Address Before a Joint Session of the Congress on the Cessation of the Persian Gulf Conflict."

${ }^{65}$ Pfautch, "Memorandum to John Sununu: The National Welcome Home," GBPL.

${ }^{66}$ Richard Shelby, “A Patriot's Day Celebration in Hueytown, Alabama," May 7, 1991, document 208848, ME002 Messages (Sent to Groups/Organizations), Subject File - General, WHORM files, GBPL.
} 
military bases attracted the most direct military involvement, and virtually all of them hosted some sort of large-scale parade featuring several thousand troops.

Writing in 1987, the sociologist Michael Mann pointedly described the modern military, which relies on advanced technology and a smaller, professional armed force, as lending itself to "spectator sport militarism," in which the general population mobilized for war "not as players but as spectators." 67 The events organized by large American cities after the Gulf War affirmed this profound shift. In New York City, Mayor David Dinkins planned a "Mother of All Parades"- a traditional ticker-tape parade up Broadway on June 10. Such events-where Wall Street workers threw ticker-tape (or, in later years, computer paper sheets) out of office windows onto returning heroes-had been in recent years reserved for sports teams, such as the New York Mets when they won the World Series in 1969 and 1986. This one would attract between 1 million and 4.7 million spectators. ${ }^{68}$ Five thousand soldiers, led by Secretary of Defense Dick Cheney and Generals Colin Powell and Norman Schwarzkopf, kicked off the start of a 24,000-strong procession featuring various veterans' organizations, diverse community groups, and bands. ${ }^{69}$ Representatives of over fifty allied nations also marched in the parade, which caused some diplomatic problems. The parade organizers invited the Israeli Defense Forces to send a color party, even though Israel had not formally joined the coalition that fought Iraq. ${ }^{70}$ The organizers also initially invited Syria to send a delegation, although they quickly backtracked after an outcry from the families of the victims of the Lockerbie bombings. $^{71}$

While New York City may have attracted the most spectators, Washington, DC's National Victory Celebration displayed by far the most military hardware. The parade organizers, the "Desert Storm Homecoming Foundation," consisted of the three major veterans' organizations: the Veterans of Foreign Wars, the American Legion, and Disabled American Veterans. They initially scheduled the parade for July 4 but moved it to June 8 , ostensibly because Congress would still be in session then, but actually to upstage New York's parade. ${ }^{72}$ General Schwarzkopf led 8,800 troops on their march through DC, and then joined President Bush on the reviewing stand. A twelve-minute-long flyby by over eighty aircraft, led by a lone F-117 stealth fighter, an icon of the war, capped off the event, which also included thirty-one heavy military vehicles, among them the M1A1 Abrams main battle tank and the Patriot missile system. ${ }^{73}$ Major General William Streeter, Commanding General of the Military District of Washington, provided commentary on both the troop formations and various weapons and vehicles for C-SPAN, while CBS News correspondent Eric Engsberg reported that there was "so much military hardware moving, at times it seemed as if Washington was under attack."74

\footnotetext{
${ }^{67}$ Michael Mann, “The Roots and Contradictions of Modern Militarism," New Left Review 162 (Mar.-Apr. 1987): 35-50, here 48 .

${ }^{68}$ Robert D. McFadden, "New York Salutes in a Ticker-Tape Blizzard, New York Honors the Troops," New York Times, June 11, 1991, A1.

${ }^{69}$ Michael Specter and Laurie Goodstein, "Millions Honor Gulf Vets at Parade in New York," The Washington Post, June 11, 1991, A1.

${ }^{70}$ Jonathan Schachter, “IDF Invited to Gulf War Parade in NY,” Jerusalem Post, Apr. 7, 1991, 10.

${ }^{71}$ Felicia R. Lee, "Syria Invitation to Gulf Parade Is Reconsidered," New York Times, May 23, 1991, B7; Jonathan Schachter, "Syria Says No Thanks to Gulf War Parade Invite," Jerusalem Post, May 30, 1991, 10.

${ }^{72}$ Leigh Ann Metzger, "Memorandum for the President: Meeting with Desert Storm Homecoming Foundation," Apr. 18, 1991, folder 12918 Iraq [1991] [4], Alphabetical Subject Files, Marlin Fitzwater Files, White House Press Office, GBPL.

73“Bush Unfurls Desert Storm Day of Pride Gulf War Veterans Get Extravaganza," The Baltimore Sun, June 9, 1991, 1 A.

74"National Victory Celebration Parade," C-SPAN, June 8, 1991, https://www.c-span.org/video/?18328-1/ national-victory-celebration-parade (accessed Nov. 25, 2018); Caroline Linton, "How CBS News Reported the Last National Military Parade in 1991," CBS News, Feb. 7, 2018, https://www.cbsnews.com/news/how-cbs-newsreported-the-last-national-military-parade-in-1991/ (accessed Nov. 25, 2018).
} 
Seven blocks of the National Mall were also dedicated to what bemused reporters called a "military petting zoo" of weaponry and equipment. One exhibit tent contained every type of bomb and missile used in the war, while others allowed visitors to try on a gas mask or practice laying a howitzer on the Washington Monument.

Indeed, such was the scale and bulk of the hardware on display that National Park Service personnel worried about tanks tearing up the Mall and damaging the sprinkler system underneath. Some asked questions about whether or not the bridges over the Potomac, designed for civilian traffic, could bear the weight of the seventy-ton Abrams tanks. The military put in place traffic regulations allowing only one tank to cross the bridge at a time, keeping to under thirty miles per hour and at least two feet away from the curb on either side. Electric and phone companies worried about damage to their cables, and several street lights had to be removed so that the Patriot Missile Launcher vehicle could get through. Designing a parade route that did not cross any of Washington, DC's metro tunnels and stations, as engineers feared they might collapse under the weight of the vehicles, proved most difficult of all. ${ }^{75}$

The eventual parade route stretched just over two and a half miles long, but the event attracted only around 200,000 spectators, far below the one million that organizers had hoped for. The crowd featured a heavy contingent of federal employees and defense contractors, a group that one reporter observed was "tightly connected to the military and the bureaucracy, closer than most of the country to weapons and the workaday of war."76 Along with the "military petting zoo" on the Mall and the hardware-heavy parade and flyby, the Pentagon chose to use the week following the parade to promote its budget priorities. It promoted an "Air Force Stealth Week" at nearby Andrews Air Force Base where reporters could visit the base and see a selection of stealth aircraft, including a prototype of the F-22 Raptor, the F-117 Nighthawk, and the B-2 Spirit. Not coincidentally, Congress had recently threatened to cancel the B-2's building program. ${ }^{77}$ For the Pentagon, then, the National Victory Celebration was a chance not just to welcome home the "half million heroes" their Public Affairs Office invoked in discussions with the White House, but also to aggressively promote budget priorities in the post-Cold War spending drawdown.

The Los Angeles parade on May 19 featured almost as much military hardware as its Washington counterpart, with a flyby by four F-117 Nighthawks and a parachute jump by six flag-waving paratroopers. That evening saw a huge fireworks display, including the simulated shoot-down of an Iraqi Scud missile by a Patriot Missile. ${ }^{78}$ The Raytheon corporation also provided a seventeen-foot, two-thousand-pound replica Patriot Missile for the parade, "symbolizing the partnership of technology and the traditional role of the citizen soldier."79 Additionally, the missile held a time capsule containing military memorabilia and unit flags to be opened by Gulf War veterans twenty-five years later. More than 4,000 troops took part, followed by 2,000 veterans of other wars, bands, color guards, and celebrities such as Roseanne Barr, Tony Curtis, and Gene Autry. Jimmy Stewart and Bob Hope served as honorary co-chairmen, and Hope declared of the war: "That's the way all wars should be, real fast like that and get the hell out and get home." 80

Some commentators did regard the pageantry of the parades with disdain. One, for example, argued that the Hollywood event had "the kind of Disneyesque tone worthy of the Rose Parade,

\footnotetext{
${ }^{75}$ Mary Jordan, “D.C. Parade Plans Roar into Focus," The Washington Post, May 16, 1991, A1.

${ }^{76}$ Associated Press, “200,000 View War Victory Parade," Pittsburgh Press, June 9, 1991, A1.

${ }^{77}$ Fred Kaplan, "Air Force Opens Up to Save Its Stealth Capitol Hill Pitch Plays on Gulf War Parades," Boston Globe, June 11, 1991, 3.

${ }^{78}$ Associated Press, "Hollywood Welcome-Home Parade Draws 1 Million," Las Vegas Review-Journal, May 20, 1991, 4A.

${ }^{79}$ Michael D. Antonovich, "Letter to Linda DeHart," May 8, 1991, document no. 208848, ME002 Messages (Sent to Groups/Organizations), Subject File - General, WHORM files, GBPL.

${ }^{80}$ Associated Press, “Tinseltown Gives Gulf Vets Huge Parade,” Northwest Florida Daily News, May 20, $1991, \mathrm{~A} 1$.
} 
as if Mickey Mouse and an M-1 tank were identical twins." ${ }^{81}$ Others noted that the time spent on celebrations outstripped the length of the war itself and meanwhile people in Iraq now endured an "emerging tragedy of starvation and dislocation." ${ }^{82}$ But others pushed back against the criticisms. Writing in the Washington Post, Charles Krauthammer acidly countered that complaints about militarism and triumphalism missed the essentially harmless nature of the celebrations:

What are the critics so lathered up about? Triumphalism? The Romans knew how to put on a triumph: The general wore a golden crown, the enemy marched in chains, and wagons of booty brought up the rear. Today's endlessly televised, absurdly choreographed Hollywood parades given to patriotic crooning by second-string soap stars are not triumphs. They are Trumps (of the Donald variety), exercises in mildly amusing vulgarity. ${ }^{83}$

For Krauthammer, “America's genius ... is not militarism but show biz. This isn't 'Triumph of the Will.' This is 'Gilligan's Island." 84 If this was militarism, in other words, then it was militarism with a particularly American twist.

As much as these events relied on star power and spectacle, they also required heavy corporate sponsorship. In New York City, Mayor Dinkins faced a public outcry when he worried that the city's budget crisis meant it would struggle to meet the expense of its parade. ${ }^{85}$ In response, the organizers enlisted American Express as both corporate sponsor and fundraising coordinator. The firm acquired over $\$ 10$ million in donated advertising time to look for contributions and set up a toll-free hotline where citizens could donate to the parade by credit card. After initial worries, the organizers evidently had no trouble raising the $\$ 4.3$ million needed to stage the parade. ${ }^{86}$ Businesses were also quick to donate goods and services, with one company donating 140 miles of yellow ribbon. ${ }^{87}$ In Washington, DC, the Department of Defense paid \$7 million toward the cost of the parade, with private donations-including $\$ 1$ million from the Saudi and Kuwaiti governments and large contributions from Coca-Cola, AT\&T, Walmart, and dozens of other firms-making up another $\$ 5$ million. ${ }^{88}$

The homecoming celebrations also provided advertising opportunities: in the Hollywood parade, a new soft drink called Combat Cooler (which came in a desert camouflage can) sponsored a float honoring the U.S. Department of Veterans Affairs, while Kodak's float carried the newly crowned "Miss Universe." When the military aircraft finished their show, civilian airplanes hauled banners over the route with such messages as "Welcome Home Troops from Downey Toyota" and "Welcome Home Troops-Pick-Your-Part Auto Wrecking." Hollywood parade organizer Johnny Grant also served as vice president of local TV station

\footnotetext{
${ }^{81}$ Howard Rosenberg, “A Parade of TV Praise for Gulf Warriors, War,” Los Angeles Times, May 21, $1991, \mathrm{~F} 1$.

${ }^{82}$ David Evans, “Gulf War Victory Mega-Parade: It's Too Much, Too Soon,” Chicago Tribune, June 7, $1991,25$.

${ }^{83}$ Charles Krauthammer, "In Praise of Parades," Washington Post, May 24, 1991, A23.

${ }^{84}$ Ibid.

${ }^{85}$ David Gonzalez, "Gulf Veterans to Be Honored in May Parade," New York Times, Mar. 4, 1991, B1.

${ }^{86}$ Robert D. McFadden, "Fund-Raising on Target for Whopping Victory Parade," New York Times, May 13, 1991, B1.

${ }^{87}$ Jerry Gray, “A Gulf Parade with Six Tons of Ticker Tape,” New York Times, June 6, 1991, B1.

${ }^{88}$ Kristin Huckshorn, "Parade May Cost Taxpayers \$7 Million," Orange County Register, June 7, 1991, A10.

${ }^{89}$ Scott Harris and Josh Meyer, "Gulf Troops Welcomed with Hollywood Flair Parade," Los Angeles Times, May 20, 1991, 1. One proposal sent to the White House called for a National Alliance for Business-led "Salute to the Armed Forces." This "American Patriotic Spectacle" would offer "prominent sponsorship opportunities for all the multi-national companies representing the Allied Nations" and would provide "a unique exposure opportunity for the aerospace and oil companies to heighten their community service image." This event would include a special souvenir album and an extensive merchandising program. Jeff S. Jani, "Letter to Spencer E. Geissinger," Feb. 11, 1991, folder 04733-007, Desert Storm: Presidential Messages/Videos, Sig Rogich Files, White House Office of Public Events and Initiatives, GBPL.
} 
KTLA. The station claimed exclusive broadcasting rights to the event and announced plans to charge rivals $\$ 250,000$ for the footage. ${ }^{90}$ Other TV stations, such as KCAL-TV, countered that since it was a public event, they intended to turn up with their cameras anyway and threatened legal action. The organizers resolved the dispute when the mayor of Los Angeles became uneasy about subsidizing a profit-making venture and KTLA dropped the charge. ${ }^{91}$

\section{Welcoming Them Home "As Human Beings, Not as Victors": Protestors and Veterans}

The White House and Department of Defense had not necessarily anticipated on this sort of gaudy commercialism, even if officials were happy to welcome more discreet forms of corporate involvement and sponsorship. But the variety in event styles across the United States pointed to some ways in which ordinary Americans interacted with these celebrations. As Kurt Piehler has argued, "remembering war the American way" has usually meant that the federal government allowed local communities to determine who and what to honor. ${ }^{92}$ John Bodnar has similarly claimed that public memory emerges from the intersection of official and vernacular cultural expressions. ${ }^{93}$ Certainly, the celebrations of 1991 , these early attempts to commemorate the Gulf War, reflected that divide to some degree. On the one hand, large, happy audiences eagerly attended parades, organized their own homecomings, and thanked every veteran they could find. On the other hand, even at this moment of intense triumphalism, many Americans dissented from the narratives of victory. There were a number of arrests in both New York City and Washington, DC, and parades in other cities also attracted small numbers of protestors.

Remarkably, protests actually managed to derail attempts to organize a victory parade in Seattle. Like other cities such as San Francisco (which had declared itself a sanctuary for any deserters from the Gulf War), Seattle had seen major antiwar and pro-war protests prior to Desert Storm. In an effort to placate both sides, Seattle Mayor Norm Rice invited both proand antiwar groups to form a parade organizing committee. ${ }^{94}$ But these groups argued over the composition of the parade, and antiwar activists asked for the troops to march without any weapons. Military officials from nearby Fort Lewis refused to allow troops to participate in the parade without their arms and declared that they would send only their band and hospital units. ${ }^{95}$ The peace groups eventually agreed to permit rifles and helmets but balked when military officials insisted on adding Chapperal anti-aircraft missile launchers, armored personnel carriers, and trucks. At that point, the antiwar groups pulled out of the parade committee and began planning a countermarch. ${ }^{96}$ Meanwhile, the parade organizers struggled to fundraise, falling $\$ 90,000$ short of their $\$ 250,000$ goal. ${ }^{97}$ Eventually, amid acrimony, the city cancelled the parade entirely-a remarkable development in a summer full of bombastic displays of militaristic patriotism. Following the collapse of the parade, the mayor's office scrambled to find an alternative celebration to replace the scheduled June 22 event. It eventually settled on a "welcome home week" coordinated with the annual SeaFair Torchlit parade in August, inviting members of the military to march in that procession and offering free admission to sporting events, the aquarium, and the zoo for troops and their families. Significantly, the 1,000 troops in this alternative parade would march unarmed. Pro-war groups grudgingly

\footnotetext{
${ }^{90}$ Josh Meyer, "Raining on Their Gulf War Parade Hollywood," Los Angeles Times, Apr. 4, 1991, 1.

${ }^{91}$ Josh Meyer, "Peace Will Reign over Hollywood Parade for GIs," Los Angeles Times, Apr. 11, 1991, 1.

${ }^{92}$ Piehler, Remembering War the American Way.

${ }^{93}$ John Bodnar, Remaking America: Public Memory, Commemoration, and Patriotism in the Twentieth Century (Princeton, NJ, 1993), 13-14.

${ }^{94}$ Ed Offley, "10,000 Troops to March in Parade Picnic, Concert Also Planned for Vets Returning from Gulf," Seattle Post - Intelligencer, Apr. 23, 1991, B2.

${ }^{95}$ Ross Anderson, "Welcome Home for Troops Sets Off a War," Seattle Times, Apr. 30, 1991, A1.

${ }^{96}$ Ken Fireman, "Seattle Storms over Gulf War Parade," Newsday, May 17, 1991, 07.

${ }^{97}$ Robert T. Nelson, "Seattle Cancels War Parade," Seattle Times, June 5, 1991, A1.
} 
assented to this plan, and antiwar activists approvingly declared that they had always wanted an "an event that welcomes the troops home 'as human beings, not as victors." 98

In Los Angeles, attempts by protestors to shape public perception of the celebrations enjoyed less success. There, members of antiwar group SANE/FREEZE decided that rather than protesting the parade from the outside, as others had done in New York, Washington, and other cities, they would participate in it as marchers. Activist Jerry Rubin claimed antiwar sentiment as an American tradition, proclaiming that "we want to participate in the parade to put forth our peace message.... Peace people shouldn't be left on the periphery, as outcasts." Fellow activist Grace Aaron said she considered the show of military hardware "obscene," but added: "It's more appropriate for us to be part of the parade than to be simply a counterdemonstrationfrom the outside looking in.... We have every right to march. We are citizens. We do pay taxes." 99 Initially, the parade organizers indicated that they might be able to accommodate the antiwar protestors, but finally decided that they would not, as such participation would disrespect the veterans the parade intended to honor. Indeed, the organizers feared what the veterans might do to the protestors. One parade organizer argued that the activists simply did not understand the degree of animus many veterans felt towards them. He said that "we have some Vietnam veterans who have a great deal of hostility toward the peace movement because of the way they were treated when they got back from Vietnam.... One motorcycle veterans' group said put them in front of us. Another veterans group said put them behind us. I think they had an ulterior motive for wanting them close by."100

As the use of veterans to block the participation of protestors in the Hollywood parade revealed, the outpouring of support for American soldiers and veterans included a narrowing of the terms of political debate. It was now more difficult, almost impossible, for protest groups to put forward antiwar arguments without being depicted as unpatriotic. The inclusion of Vietnam veterans in these parades, moreover, contained a critique of the antiwar movement's treatment of soldiers returning from that earlier war. The commemorative pamphlet produced for Washington, DC's National Victory Celebration made this clear when it included an account from a Gulf War veteran of the welcome he received from a wheelchair-bound Vietnam veteran. The Desert Storm veteran hoped and prayed that "our welcome home will in some small way make up for the one he and his brother never got." 101

Vietnam veterans played prominent roles in the planning and execution of many of the parades. During the Philadelphia celebrations, for example, two Vietnam veterans symbolically passed a U.S. flag and a POW-MIA flag to two Gulf veterans. ${ }^{102}$ Other parades also featured marching Vietnam veterans: in Chicago, Chairman of the Joint Chiefs of Staff General Colin Powell and Secretary of Veterans Affairs Edwin Derwinksi, both veterans, served as grand marshals, and a group of 350 Vietnam veterans received loud cheers as they marched. ${ }^{103}$ In Hollywood, none other than General William Westmoreland, the former commander of U.S. forces in Vietnam, led a large contingent of Vietnam veterans. Westmoreland told reporters that "any time I can be with the troops it's an exhilarating experience ... there's lots of

\footnotetext{
${ }^{98}$ Mark Andrejevic, "Bremerton Parade to Honor Gulf Troops," Kitsap Sun, June 14, 1991, https://products.kitsapsun.com/archive/1991/06-14/2485_bremerton_parade_to_honor_gulf_tr.html (accessed Dec. 19, 2018).

${ }^{99}$ Scott Harris, "Hollywood Salute to Gulf War Vets Draws Some Fire," Los Angeles Times, Apr. 22, $1991,1$.

${ }^{100}$ Scott Harris, "Gulf Parade Rejects Bid by Anti-War Activist Desert Storm," Los Angeles Times, Apr. 27, $1991,2$.

101"Desert Storm: A Commemorative Salute" (Grabhorn Studio Inc, June 8, 1991), folder 08809-02, Miscellaneous Files: Desert Storm [2], White House Office of National Service, GBPL.

${ }^{102}$ Weightman Public Relations, "Press Release: Vietnam Veterans Salute Persian Gulf Veterans in an Emotional Independence Day in Philadelphia," June 19, 1991, folder 04733-005, “Desert Storm: Events," Sig Rogich Files, White House Office of Public Events and Initiatives, GBPL.

103“Chicagoans Line Up 15 Rows Deep for Parade Honoring Gulf Veterans," Los Angeles Times, May 11, 1991, 18; Edward Walsh and Lauren Ina, "Chicago Cheers Gulf Vets; Parade Also Salutes Vietnam Soldiers," The Washington Post, May 11, 1991, A3.
} 
camaraderie." He also noted that "I don't think we've ever seen a time in history when the country is so elated and so happy about the great success of a war." ${ }^{104}$ Westmoreland received loud cheers from Vietnam veterans when he appeared on parade, even as some veteran groups refused to participate because of his presence. ${ }^{105}$

Some veterans of earlier wars found the adulation for Gulf War veterans harder to stomach. In Orange County, California, Vietnam veteran Dan Baldwin spoke about the Desert Storm veterans to reporters as he attended a homecoming parade: "These guys did a hell of a fine job over there.... I'm proud of them, but there's a bit of jealousy." Baldwin saw a stark difference between the two wars: "Here they are getting a parade, well-deserved as it is, for eight months of work and 100 hours of war. I was in Vietnam for 13 months, wounded twice. There was nothing for us. But it's a different society today." ${ }^{106}$ Writing to the Louisville Courier-Journal on Veterans Day and looking back at the summer of celebratory homecomings, World War II veteran Frank O'Rourke complained about both the adulation for the Gulf War veterans and the grievances of Vietnam veterans. O'Rourke pointed out that the vast majority of veterans did not actually see combat and that the "war for them will be remembered as an experience from their youth that they can reminisce about the way college students do about a big football game." 107 Further, there was something off-putting about these parades, where "soldiers looked the way civilians thought victorious soldiers should look—clean shaven, pressed uniforms, shiny boots, bands playing, and flags flying," more like a championship-winning football or baseball team.

In contrast, O'Rourke recalled his own experience, when he, like most experienced combat veterans, opted to leave the 82nd Airborne Division early rather than delay his discharge to take part in the homecoming parade. When he attended the division's 1946 parade down Fifth Avenue in New York City as a civilian onlooker, he saw a division full of fresh recruits that the Army had rushed in to replace the departed veterans. O'Rourke wished instead for a less sanitized parade-one that featured his unit when they came out of the Battle of the Bulge: "just columns of guys straggling down Fifth Avenue, shuffling along on frostbitten feet, with hand grenades tucked in the webbing of their harnesses, M-1s slung over their shoulders, bearded faces, gaunt eyes, hollow eyes, fatigued, exhausted physically and emotionally." 108 Instead, he saw the Gulf War homecomings as a continuation of a deception about the nature of war.

Generally, though, the wave of celebrations across the country drowned out perspectives like O'Rourke's. Given the ubiquity and intensity of these celebrations, it is clear that they represented widespread popular sentiment. Perhaps the most striking demonstration of the ways in which Americans embraced veterans in 1991 took place at Bangor International Airport, Maine. Bangor became a major transit point for troops returning from the Middle East. Throughout the spring and summer of 1991, approximately 220 flights landed there, containing some 60,000 veterans of Operation Desert Storm. Local civic groups organized a roster of greeters so that every flight, whether it landed in the middle of the night or during the working day, would be met with an enthusiastic crowd of locals offering coffee, small gifts, free phone calls, embraces, and handshakes. ${ }^{109}$ The mood at the airport was generally euphoric: greeters pinned yellow ribbons on the veterans, and soldiers autographed children's commemorative Desert Storm t-shirts. On one of the initial flights, on March 8, Sergeant Kevin Tillman grabbed

\footnotetext{
${ }^{104}$ Associated Press, “Tinseltown Gives Gulf Vets Huge Parade,” A1.

${ }^{105}$ Harris and Meyer, "Gulf Troops Welcomed with Hollywood Flair Parade," 1; Rosenberg, "A Parade of TV Praise for Gulf Warriors, War," F1.

${ }^{106}$ Gary A. Warner, "Hero's Welcome Far Cry from Vietnam," Orange County Register, May 19, 1991, A14.

${ }^{107}$ Frank J. O’Rourke, “Parade of Veterans," The Courier-Journal, Nov. 11, 1991, 6.

${ }^{108}$ O'Rourke, "Parade of Veterans," 6.

${ }^{109}$ Brian Swartz, An American Homecoming (Bangor, ME, 1996); Lynne Junkins Cole, Goodbye Desert Storm, Hello Bangor, Maine: Experience Welcoming the Troops through the Eyes of the Greeters (Hampden, ME, 1991).
} 
a saxophone and played a rendition of the "Star-Spangled Banner" from the steps of the plane to a cheering crowd. ${ }^{110}$

The organizers made the point that their greeting party had "nary a politician or bureaucrat in its ranks." 111 One greeter claimed that "we as a nation can't afford to repeat the mistakes we made with the troops in Vietnam. It's time to welcome home a new generation of veterans." "112 Similarly, local journalist Brian Swartz argued that the Bangor homecomings "had flipped the page historically by welcoming home our veterans, not by castigating them for obeying their civilian superiors' orders and policies" and that the greeters honored "them for what they were: the best of the best, American men and women who had gone into harm's way for the rest of us." ${ }^{\prime 13}$ Some members of the American Legion and Veterans of Foreign Wars even made a point of chasing any service members embarrassed by the welcome out from the ramp and into the waiting arms of the crowd "where they belonged." 114 Whether they wanted it or not, Gulf War veterans would receive a loud and public welcome home in Bangor. So extensive were the homecoming celebrations, which continued until September 1991, that the city held a special ceremony to thank the greeters in August 1991. At that ceremony Lieutenant General John Yeosock, who had commanded the U.S. 3rd Army in the Gulf, told the crowd that, much as he had been heartened by the groundswell of public support marked by the volume of care packages and mail sent to the troops, the scale of the phenomenon had not occurred to him until he landed in Bangor. But now he had no doubt that the greeters "manifested the totality of what it was that this great nation of ours came to believe, feel, understand, and do."

\section{Conclusion}

In 2003, the citizens of Bangor re-activated their troop greeting committee and a mix of veterans' groups and ordinary citizens again began to greet every military flight. This time the greetings extended over years, and indeed even decades, as various post-9/11 wars saw over 1.4 million troops and seven thousand flights land in Bangor. ${ }^{116}$ The euphoria of the summer of 1991 had disappeared, but the same repertoire of homecoming gestures remained: hot coffee, handshakes, shouts of "welcome home" and "thank you for your service." Communications scholar Lisa Silvestri has argued that such homecomings represent a politics of "vicarious sacrifice," where participants combine emotional identification with the service members and their families with political passivity on larger questions of war and peace. ${ }^{117}$ From airline boarding privileges for soldiers to military displays at sporting events, these rituals have become pervasive in American society. They contain a politics deeply antithetical to critical dissent, one that inflected, for instance, the recent difficulties that NFL players protesting police brutality encountered after conservative commentators accused them of disrespecting the

\footnotetext{
110“20 Years Later, Sax-Playing Soldier Helps John Bapst Band Send off Troops,” Bangor Daily News, Oct. 19, 2011, https://bangordailynews.com/2011/10/19/news/bangor/20-years-later-sax-playing-soldier-helps-john-bapstband-send-off-troops/ (accessed Dec. 19, 2018).

${ }^{111}$ Swartz, An American Homecoming, 2.

${ }^{112}$ Ibid., 15.

${ }^{113}$ Ibid., v.

${ }^{114}$ Ibid., 26.

${ }^{115}$ Ibid., 227.

${ }^{116}$ Nok-Noi Ricker, "As Military Flights through Bangor Dwindle, Maine Troop Greeters Work to Preserve Their History," The Bangor Daily News, Jan. 24, 2014, https://bangordailynews.com/2014/01/24/news/bangor/ maine-troop-greeters-working-to-preserve-their-history-as-military-flights-through-bangor-airport-dwindle/ (accessed Dec. 19, 2018); The Maine Troop Greeters and Museum, http://www.themainetroopgreeters.org/ (accessed Dec. 20th, 2018).

${ }^{117}$ Lisa Silvestri, "Surprise Homecomings and Vicarious Sacrifices," Media, War \& Conflict 6, no. 2 (Aug. 2013): $101-15$.
} 
troops. ${ }^{118}$ These contemporary political dynamics trace back to the spring and summer of 1991, when millions of Americans turned out to welcome Gulf War veterans-and by extension, veterans of other wars-home. The history of those homecomings suggests that the seemingly deep-rooted militarism of twenty-first-century American society relied on the specific and contingent wartime and postwar dramas designed to elicit patriotic demonstrations and displays of gratitude.

The various Gulf War victory parades were not identical, nor did they contain the same meaning for everyone. While members of the Bush administration and the Department of Defense may have been eager to celebrate the success of the All-Volunteer Force and promote American technological superiority, they could not control how disputes over TV rights marred parade planning in Los Angeles, nor could they do much about the antiwar protestors in Seattle who intended to welcome the troops home as "human beings rather than as victors." The celebrations in smaller towns often placed comparatively heavier emphasis on veterans and individual soldiers than those in the large cities, which, because of the greater scale of official involvement, did more to highlight weapons systems and celebrate the military as an institution.

Although unconditional support for the troops rose to new heights, the national mood of elation in 1991 did not last. Bush's popularity sank to the extent that he lost his re-election campaign the following year. In addition, the post-Cold War drawdown reduced U.S. military ranks considerably, from 2.17 million troops in 1987 to 1.37 million in $2000 .{ }^{119}$ Veterans of the Gulf War struggled, as their Vietnam-era predecessors did, to access healthcare services, not least when it came to the "Gulf War Syndrome," an illness that many attributed to exposure to environmental hazards during the war. ${ }^{120}$

What did endure, however, was the notion-common to official celebrations and spontaneous small-town gatherings, war veterans, and local TV stations-that soldiers and veterans represented the best qualities of the United States. Instead of being seen as troubled and potentially disruptive veterans bringing home psychological baggage from the war, politicians and the broader public celebrated the Gulf War veterans-and implicitly all veterans-as possessing all of the traits that the United States would need to succeed in the next century. In one of the major foreign policy speeches of his primary campaign, Governor Bill Clinton of Arkansas placed the troops at the heart of his peroration. Recalling the 100,000-strong crowd that had attended Little Rock's welcome home parade, Clinton spoke about how he felt moved as he watched "the men and women who had served in World War II, Korea, and Vietnam ... march down the street to our cheers and saw the Vietnam veterans finally being given the honor they deserved all along." For Clinton, this moment emerged as one in which "the divisions we have lived with for the last two decades seemed to fade away amid the common outburst of triumph and gratitude." ${ }^{121}$ In truth, the divisions in American society had hardly faded, but nobody could escape the language of gratitude; even antiwar activists now used the language of supporting the troops in their protests.

\footnotetext{
${ }^{118}$ Josh Hafner, “Anthem Kneeling Isn't Aimed at Veterans, and Other NFL Protest Misconceptions," USA Today, Sept. 25, 2017, https://eu.usatoday.com/story/news/nation-now/2017/09/25/anthem-kneeling-isnt-aimedveterans-and-other-nfl-protest-misconceptions/701409001/, (accessed Dec. 19, 2018).

${ }^{119}$ Bernard Rostker, "Right-Sizing the Force: Lessons for the Current Drawdown of American Military Personnel” (Washington, DC, June 2013), 13, https://www.cnas.org/publications/reports/right-sizing-the-force-lessons-for-the-current-drawdown-of-american-military-personnel (accessed Nov. 25, 2018).

${ }^{120}$ Neil Greenberg and Simon Wessely, "Gulf War Syndrome: An Emerging Threat or a Piece of History?," Emerging Health Threats Journal 1 (Nov. 2008) https://www.ncbi.nlm.nih.gov/pmc/articles/PMC3167584/; Khalida Ismail, "A Review of the Evidence for a 'Gulf War Syndrome," Occupational and Environmental Medicine 58, no. 11 (Nov. 2001): 754-60.

${ }^{121}$ Stephen A. Smith, ed., Preface to the Presidency: Selected Speeches of Bill Clinton 1974-1992 (Fayetteville, AR, 1996), 124.
} 
The spring and summer of 1991 thus represented a crucial moment when the Americans' veneration for their military deepened and intensified. The last lines of the Army's official history of Operation Desert Storm revisited Steven Slocum, met with silence on his return from Vietnam and fêted after the Gulf. The authors closed with this hope: "Let the Specialist Slocums of 1991 look back in 2016 at 25 years of the same support and appreciation they felt as they stepped off the planes following their return from Desert Storm." ${ }^{22}$ Looking at what followed the summer of 1991, it seems clear that they received their wish. The adulation of millions of Americans both secured the rehabilitation of the military's place in American society and provided a template for how to speak and think about American soldiers as they continued to travel to and from their wars.

David Fitzgerald is a lecturer in the School of History, University College Cork, Ireland. Previously a Glucksman Fellow at New York University and a postdoctoral fellow at the Clinton Institute for American Studies, University College Dublin, he is the author of Learning to Forget: US Army Counterinsurgency Doctrine from Vietnam to Iraq (Stanford, CA, 2013), the co-author of Obama, US Foreign Policy and the Dilemmas of Intervention (London, 2014), and co-editor of Not Even Past: How the United States Ends Wars (New York, 2019). He is currently writing a book on militarization and the American Century, and working on a project that examines the rise of a "warrior ethos" within the post-Cold War U.S. Army.

${ }^{122}$ Scales, Certain Victory, 390. 